P ISSN : 2503 - 1708

E ISSN : 2722 - 7340

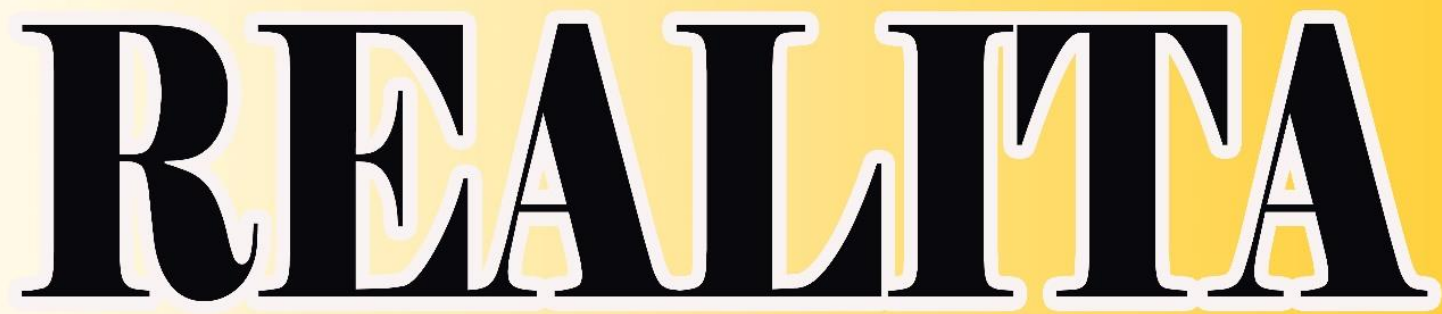

Jurnal Bimbingan dan Konseling

\begin{tabular}{|c|c|c|c|c|c|}
\hline JURNAL & VOLUME & NOMOR & EDISI & HALAMAN & P ISSN : 2503 - 1708 \\
REALITA & 6 & 2 & Oktober 2021 & $1326-1430$ & E ISSN : 2722 - 7340 \\
\hline
\end{tabular}

Diterbitkan oleh:

PROGRAM STUDI BIMBINGAN DAN KONSELING FAKULTAS ILMU PENDIDIKAN DAN PSIKOLOGI UNIVERSITAS PENDIDIKAN MANDALIKA 


\section{REALITA \\ BIMBINGAN DAN KONSELING \\ Jurnal Penelitian dan Pengembangan Pendidikan}

\section{DEWAN REDAKASI \\ Pelindung : Rektor Universitas Pendidikan Mandalika \\ : Dekan FIPP Universitas Pendidikan Mandalika \\ Penanggung \\ Jawab \\ : Kaprodi BK FIPP Universitas Pendidikan Mandalika \\ Editor}

Hariadi Ahmad, M.Pd

Universitas Pendidikan Mandalika

Associate Editor

Mustakim, M.Pd

Universitas Pendidikan Mandalika

Mujiburrahman, M.Pd

Universitas Pendidikan Mandalika

Ahmad Muzanni, M.Pd

Universitas Pendidikan Mandalika

M. Chaerul Anam, M.Pd

Universitas Pendidikan Mandalika

\section{Editorial Board}

Prof. Drs. Kusno, DEA., Ph.D

Universitas Negeri Jember Jawa Timur

Drs. Wayan Tamba, M.Pd

Farida Herna Astuti, M.Pd

Ichwanul Mustakim, M.Pd

Reza Zulaifi, M.Pd

Jessica Festi Maharani, M.Pd

Universitas Pendidikan Mandalika

Universitas Pendidikan Mandalika

Universitas Pendidikan Mandalika

Universitas Pendidikan Mandalika

Universitas Pendidikan Mandalika

\section{Reviwer}

Dr. I Made Sonny Gunawan, S.Pd., M.Pd

Universitas Pendidikan Mandalika

Dr. A. Hari Witono, M.Pd

Universitas Mataram NTB

Prof. Dr. Wayan Maba

Universitas Mahasaraswati Bali

Dr. Gunawan, M.Pd

Universitas Mataram NTB

Dr. Haromain, S.Pd., M.Pd.

Universitas Pendidikan Mandalika

Dr. Hadi Gunawan Sakti, M.Pd

Wiryo Nuryono, M.Pd

Hasrul, S.PdI., M.Pd

Dita Kurnia Sari, M.Pd

Dr. Roro Umy Badriyah. M.Pd., Kons

Universitas Pendidikan Mandalika

Universitas Negeri Surabaya Jawa Timur

STKIP Kie Raha Ternate Maluku Utara

UIN Sunan Ampel Surabaya Jawa Timur

Universitas PGRI Maha Dewa Bali

Ari Khusumadewi, M.Pd

Universitas Negeri Surabaya Jawa Timur 
M. Najamuddin, M.Pd

M. Samsul Hadi, M.Pd

Lalu Jaswandi, M.Pd

Eneng Garnika, M.Pd

Aluh Hartati, M.Pd

Drs. I Made Gunawan, M.Pd

Nuraeni, S.Pd., M.Si

Baiq Sarlita Kartiani, M.Pd

M. Zainuddin, M.Pd

Ahmad Zainul Irfan, M.Pd

Dra. Ni Ketut Alit Suarti, M.Pd

Asep Sahrudin, S.Pd., M.Pd

Suciati Rahayu Widyastuti, S.Pd., M.Pd

Rahmawati M, S.Pd., M.Pd

Ginanjar Nugraheningsih, S.Pd. Jas., M.Or

Dewi Ariani, S.Pd., M.Pd

St. Muriati, S.Pd., M.Pd

Uli Agustina Gultom, S.Pd., M.Pd

Indra Zultiar, S.Pd., M.Pd.
Universitas Pendidikan Mandalika

Universitas Pendidikan Mandalika

Universitas Pendidikan Mandalika

Universitas Pendidikan Mandalika

Universitas Pendidikan Mandalika

Universitas Pendidikan Mandalika

Universitas Pendidikan Mandalika

Universitas Pendidikan Mandalika

Universitas Pendidikan Mandalika

Universitas Pendidikan Mandalika

Universitas Pendidikan Mandalika

Univ. Mathla'ul Anwar Banten

Univ. Nahdlatul Ulama Cirebon

Universitas Muhammadiyah Kendari Sulawesi Tenggara

Universitas Mercu Buana Yogyakarta

Universitas Mahaputra Muhammad Yamin Solok Sumatera Barat

Universitas Bosowa Makassar Sulawesi Selatan

Universitas Borneo Tarakan Kalimantan Utara

Universitas Muhammadiyah Sukabumi Jawa Barat

\section{Alamat Redaksi:}

Redaksi Jurnal Realita Bimbingan dan Konseling (JRbk)

Program Studi Bimbingan dan Konseling

Fakultas Ilmu Pendidikan dan Psikologi Universitas Pendidikan Mandalika

Gedung Dwitiya, Lt. 3 Jalan Pemuda No. 59 A Mataram Telp. (0370) 638991

Email : realita@undikma.ac.id

Web : e-journal.undikma.ac.id

Jurnal Realita Bimbingan dan Konseling menerima naskah tulisan penulis yang original (belum pernah diterbitkan sebelumnya) dalam bentuk soft file, office word document (Email) atau Submission lansung di akun yang diterbitkan setiap bulan April dan Oktober setiap tahun.

Diterbitkan Oleh: Program Studi Bimbingan dan Konseling Fakultas Ilmu Pendidikan dan Psikologi Universitas Pendidikan Mandalika. 


\section{DAFTAR ISI}

Halaman

\section{Nuraeni dan Mastari}

Pengaruh Konseling Kelompok Terhadap Self Esteem Siswa Kelas XI di SMK Negeri 2 Kuripan

\section{Aprilia Yolanda, Ni Ketut Alit Suarti dan Ahmad Muzanni}

Pengaruh Body Shaming Terhadap Kepercayaan Diri Siswa SMA Negeri

1 Batulayar

$1342-1353$

\section{Hariadi Ahmad}

Hubungan Kestabilan Emosi dengan Kontrol Diri Siswa Sekolah Menegah Pertama

\section{Aluh Hartati}

Pengaruh Teknik Modeling Untuk Meningkatkan Empati Siswa

\section{Mustakim}

Pengaruh Teknik Cerita Terhadap Sikap Kemandirian Anak Pada Usia 5-6 Tahun

\section{Farida Herna Astuti dan Ichwanul Mustakim}

Keefektifan Bimbingan Kelompok dengan Teknik Role Playing untuk Meningkatkan Motivasi Belajar

\section{Mujiburrahman dan Soba Al-Qadri}

Hubungan Antara Kemampuan Kontrol Diri Dengan Penyusaian Diri Pada Siswa Kelas XI SMA Negeri 1 Taliwang

\section{Wiwiek Zainar Sri Utami}

Pengaruh Konseling Individu Terhadap Potensi Diri Anak Tunarungu di Sekolah Inklusi

\section{Baiq Nur'aini Cahya Khairani dan Ni Made Sulastri}

Pengaruh Layanan Konseling Humanistik Terhadap Perilaku Agresif pada Siswa Kelas XI IPS-4 di SMA Negeri 7 Mataram

\section{Najamudin}

Pengaruh Teknik Biblioterapi Terhadap Sikap Kemandirian Belajar Pada Siswa VIII SMP Negeri 5 Lembar

\section{Khaerul Huda}

Meningkatkan Pengetahuan dan Pemahaman Perilaku Hidup Bersih dan Sehat dimasa Covid 19 Melalui Metode Demontrasi pada Kelompok B di TK Negeri 01 Wanasaba 


\title{
HUBUNGAN KESTABILAN EMOSI DENGAN KONTROL DIRI SISWA SEKOLAH MENEGAH PERTAMA
}

\author{
Oleh: \\ Hariadi Ahmad \\ Dosen Program Studi Bimbingan dan Konseling Fakultas Ilmu Pendidikan dan \\ Psikologi Universitas Pendidikan Mandalika \\ Email: hariadiahmad@undikma.ac.id
}

\begin{abstract}
Abstrak. Dalam proses kegiatan belajar mengajar kestabilan emosi sangat diutamakan karna sangat besar pengaruhnya terhadap siswa-siswa yang lain, contoh kalau pada saat guru mengajar ada beberapa siswa yang tidak memiliki kestabilan emosi maka situasi dalam kelas akan terganggu. Maka yang dimaksud dengan Kestabilan Emosi adalah keadaan emosi seseorang yang stabil dalam menyesuaikan diri dengan lingkungannya untuk mencapai kesejahteraan dan kenyamanan dirinya. Kestabilan emosia dalah tidak berlebih-lebihannya dalam mengungkapkan emosi karna emosi yang diungkapkan secara berlebihan membahayakan kesehatan fisik dan psikis manusia. Tujuan penelitian ini adalah untuk mengetahui hubungan kestabilan emosi dengan kontrol diri Pada Siswa SMP. Sedangkan Rumusan masalah apakah ada hubungan antara kestabilan emosi dengan kontrol diri pada siswa SMP. Adapun jumlah populasi sebanyak 323 siswa dan jumlah sampelnya adalah 30 siswa. Metode yang digunakan dalam penelitian ini adalah: Meode angket, Metode dokumentasi, Metode observasi dan metode observasi. Anlisis data menggunakan analisis statistic dengan rumus: korelasi producmomen. Dari hasil penelitian dan analisis data diperoleh nilai $r x y$ hitung adalah 0.384 sedangkan nilai rxy dalam tabel dengan taraf signifikan $5 \%$ dan $\mathrm{N}=30$ adalah 0,361 lebih besar dari pada rxy hitung $(0,384>0,361)$, Sehingga dapat disimpulkan bahwa ada Hubungan yang"Signifikan" kestabilan emosi dengan kontrol diri Siswa SMP.
\end{abstract}

\section{Kata kunci : Kestabilan emosi dan Kontrol diri}

\section{PENDAHULUAN}

Dalam proses kegiatan belaja rmengajar kestabilan emosi sangat diutamakan karna sangat besar pengaruhnya terhadap siswa-siswa yang lain, contoh kalau pada saat guru mengajar ada beberapa siswa yang tidak memiliki kestabilan emosi maka situasi dalam kelas akan terganggu. Maka yang dimaksud dengan Kestabilan Emosi adalah keadaan emosi seseorang yang stabil dalam menyesuaikan diri dengan lingkungannya untuk mencapai kesejahteraan dan kenyamanan dirinya. Sedangkan Menurut (Stephen P. Robbins \& Timothy A. Judge, 2008) bahwa kestabilan emosi adalah tidak berlebihlebihannya dalam mengungkapkan emosi karna emosi yang diungkapkan secara berlebihan membahayakan kesehatan fisik dan psikis manusia.
Berdasarkan beberapapen dapat tersebut peneliti dapat menyimpulkan bahwa kestabilan emosi adalah keadaan seseorang yang stabil dan tidak berlebihlebihan dalam mengungkapkan sesuatu dan dapat menyesuaikan diri dengan lingkungannya. Adapun indicator kestabilan emosi antara lain: (1) bersikap tenang (2) santai (3) nyaman dengan lingkungan sekitar. Bila kestabilan emosi terwujud pada masing-masing siswa maka dalam mengikuti proses belaja rmengajar situasi kelas semakin tenang, nyaman dan kondusif. Disamping itu pula semua guru selalu berusaha menciptakan situasi kelas yang tenang dan nyaman sehingga siswa akan mampu mengontrol dirinya dengan baik dalam menghadapi situasi apapun.

Maka yang dimaksuddengan kontrol diri adalah suatu kecakapaan 
individu dalam kepekaan membaca situasi kemampuan diri, lingkungan serta kemampuan untuk mengontrol, mengelola faktor-faktor perilaku siswa dengan situasi dan kondisi untuk menampilkan diri dalam melakukan sosialisasi kemampuan untuk mengendalikan perilaku kecendrungan untuk menarik perhatian keinginan untuk mengubah perilaku agar sesuai untuk orang lain, selalu nyaman dengan orang lainmenutup perasaannya. Menurut Goleman Kontrol Diri adalah keterampilan untuk mengendalikan diri dari api-api emosi yang terlihat mencolok. Tanda-tandanya meliputi ketegangan saat menghadapi stress atau menghadapi seseorang yang bersikap bermusuhan tanpa membalas dengan sikap atau perilaku serupa.

Berdasarakan beberapa pendapat diatas, maka peneliti dapat menyimpulkan bahwa kontrol diri suatu pengendalian tingkah laku seseorang yang cenderung bertindak positif dalam berfikir. Adapun indikator dari kontrol diri antara lain: (1) pengendalian tingkah laku (2) bertindak positif. Hubungan kestabilan emosi dengan kontrol diri sangat erat karena jikasiswa sudah memiliki emosi yang stabil maka akan mudah bagi siswa dalam mengontrol dirinya dalam melakukan sesuatu yang bisa menyebabkanny. Berdasarkan hasil observasi yang dilakukan pada beberapa SMP Kabupaten Lombok Tengah menunjukkan bahwa kebanyakan siswa masih belum mempunyai emosi yamg stabil hal ini ditunjukkan melalui sikap siswa yang mengalami kemarahan pada tingkat kategori tinggi yang dikarenakan siswa belum mampu mengontrol diri ketika memiliki masalah seperti diputuskan pacar, melawan guru, dan konflik dengan teman. Sebagian kemurungan akibat dari perubahanperubahan biologis dalam hubungan dengan kematangan seksual dan karena kebingungannya dalam menghadapi apakah masih sebagai anak-anak atau sebagai orang dewas,(2) siswa bertingkah laku kasar, (3) melawan guru untuk menutupi kekurangan dalam hal rasa percaya diri, hal ini terjadi pada saat guru menayakan tentang pelajaran dan siswa masih ragu untuk menjawabnya, ledakanledakan kemarahan mungkin biasa terjadi, hal ini sering kali terjadi sebagai akibat dari kombinasi ketegangan psikologis, ketidak stabilan biologis, dan kelelahan karena bekerja terlalu keras atau pola makan yang tidak tepat atau tidur yang tidak cukup.

Penelitian ini terdiri dari dua variable yaitu variable bebas (independent variabel) dan variable terikat (dependent variabel). Variabel bebas disini adalah kestabilan emosi dan variable terikatnya adalah control diri. Kedua variable tersebut ingin diperoleh data tentang hubungan antara kestabilan emosi dengan kontroldiri. Kestabilan Emosi diartikan sebagai keadaan emosi seseorang yang stabil dalam menyesuaikan diri dengan lingkungannya untuk mencapai kesejahteraan dan Kenyamanan dirinya, menyetabilkan emosi memang bukan hal yang mudah masalah yang datang bertubit-tubi, kondisi ekonomi yang kian sulit, lingkungan yang tak mendukung, serta semakin susahnya menemukan solusi atas beragam permasalahan yang menimpa kerap menjadi pemicu memuncaknya emosi didalam diri hingga tak jarang kita lepas control dalam mengekspresikan luapan emosi tersebut. Maka dari itu sanga tpenting bagi seseorang menyetabilkan emosinya sebelum melakukan sesuatu karena jika seseorang sudah mampu menyetabilkan emosi maka akan mudah bagi seseorang untuk mengontrol diri dan mampu mengendalikan tingkah lakunya dengan cara bertindak positif dalam berfikir 


\section{KAJIAN PUSTAKA}

Kestabilan Emosi diartikan sebagai keadaan emosi seseorang yang stabil dalam menyesuaikan diri dengan lingkungannya untuk mencapai kesejahteraan dan kenyamanan dirinya. Sedangkan Menurut Gerungan (2009) bahwa kestabilan emosi adalah tidak berlebih-lebihannya dalam mengungkapkan emosi karna emosi yang diungkapkan secara berlebihan membahayakan kesehatan fisik dan psikis manusia.

Berdasarkan pendapat diatas, peneliti dapat menyimpulkan bahwa kestabilan emosi adalah keadaan seseorang yang stabil dan tidak berlebihlebihan dalam mengungkapkan sesuatu dan dapat menyesuaikan diri dengan lingkungannya. Adapun indikator kestabilan emosi antara lain (1) bersikap tenang, (2) santai (3) nyaman dengan lingkungan. Rasa aman merupakan kebutuhan psikologis manusia. Jika manusia menikmati rasa aman, aktifitas jiwanya memberikan dampak positif bagi kehidupannya. Rasa percaya ini merupakan gejala jiwa yangsangat berharga untuk menunjukkan penampilan diri secara visual. Percaya diri membangkitkan kecerdasan dan pergaulan yang luas. Citra diri berkaitan dengan harga diri. Aktualitas kepribadian yang berhubungan Jurnal Pendidikan

Sensasi tubuh adalah sebagaimana yang di jelaskan sebelumnya bahwa persepsi (interprestasi) anda terhadap stimulus eksternal yang dirangsang secara otomatis oleh adanya perubahan pada tubuh anda merupakan teori lama yang dipakai dalam psikologi. Interprestasi sensasi adalah hadirnya sebuah dihadapan anda tidak hanya menimbulkan sensasi secara pisiologis tetapi juga memunculkan sebuah interprestasi. Sensasi psiologis sangat menentukan besarnya intensitas emosi, sedangkan interprestai yang merupakan komponen mental ini menentukan kualitas atau makna sebuah emosi. Respons adaptip adalah emosi yang sering dipahami dan dianggap sebagai sebuah perasaan sehingga perilaku sering dipengaruhi oleh perasaan yang dialami. Memunculkan sebuah interprestasi. Sensasi psiologis sangat menentukan besarnya intensitas emosi, sedangkan interprestai yang merupakan komponen mental ini menentukan kualitas atau makna sebuah emosi

Emosi adalah keadaan internal yang memiliki menifestasi eksternal. Adapun beberapa jenis emosi yang menunjuka kepribadian seseorang adalah (Coky:2013). Ekspresi wajah, semua emosi yang dialami manusia akan di ekspresikan melalui raut wajah. Vocal, Nada suara seseorang akan berubah seiring dengan emosi yang sedang dialaminya. Perubahan fisiologis, saat anda merasakan perubahan sebuah emosi, terdapat perubahan fisiologis yang mengiringinya, baik yang biasa anda rasakan maupun tidak. Gerak dan isyarat tubuh,sering kaliemosi seseorang akan di ekspresikan melalui gerak dan isyarat tubuhtindakan emosional banyak cara yang dilakukan oleh seseorang untuk mengekspresikan emosi yang dialaminya.

Mengenali emosi diri sendiri merupakan suatu kemampuan untuk mengenali suatu perasaan sewaktu perasaan itu terjadi. Mengelola emosi merupakan kemampuan individu dalam menangani perasaan agar dapat terungkap dengan tepat atau selaras. Prestasi harus dilalui dengan dengan dimilikinya motivasi dalam diri individu yang berarti memiliki ketekunan untuk menahan diri terhadap kepuasan dan mengendalikan dorongan hari. Kemampuan untuk mengenali emosi orang lain disebut juga empati, kemampuan seseorang untuk mengenali 
atau peduli menunjukan kemampuan empati seseorang. Kemampuan dalam membina hubungan dengan merupakan suatu keterampilan yang menunjang popularitas kepemimpinan antar pribadi.

Emosi positif adalah emosi yang mampu menghadirkan perasaan possitif terhadap seseorang yang mengalaminya. Untuk itu, dalam menumbuhkan emosi positif tersebut anda harus mengeksplorasi beberapa hal positif. Dalam setiap aktivitas rutin yang anda kerjakan dalam kehidupan sehari-hari pada saat tertentu energy dan semangat yang anda miliki pasti melemah meskipun masih harus menyelesaikan suatu pekerjaan. Oleh karena itu anda mesti mampu melawan dan mengusir rasa tersebut. Sikap mental yang kuat harus dibangun dan dibiasakan sehingga anda menjadi orang yang tangguh dan mandiri. Dengan cara ini energy emosi positif yang tersimpan dalam tubuh bisa terus dikembangkan. Dalam mengahadapi rasa stres yang bisa muncul sewaktu-waktu anda mesti mampu menguasai emosi dengan tenang. Salah satu cara sederhana yang dapat anda lakukan adalah mengatur pernapasan secara perlahan. Hal ini akan memberikan oksigen masuk kedalam aliran darah dan memberikan rasa tenang. Berbagi dengan orang lain juga bisa menjadi salah satu alternative dalam menumbuhkan emosi positif yang terpendam dalam diri anda. Sadarilah bahwa memiliki kemampuan yang dapat dimanfaatkan bagi kepentingan orang lain. Kebersamaan, keterbukaan, dan kepercayaan bersama teman, keluarga, atau sahabat dapat membuat anda lebih kuat dalam menghadapi berbagai persoalan hidup. Dalam setiap aktivitas sehari-hari yang anda jalani rasa bosan dan jenuh pasti pernah menghampiri dan memenuhi otak dan pikran anda. Oleh karena membuat kegiatan yang menyenangkan kehidupan yang dijalani sangat penting untuk menyegarkan semangat dan membutuhkan emosi positif.

Emosi negatif merupakan emosi yang selalu identik dengan perasaan tidak menyenangkan dan dapat mengakibatkan perasaan negative pada orang yang mengalaminya. Menurut Robert dkk (dalam Coky. 2013) emosi negative dan kesedihan yang berlebihan terbuktibisa mengganggu alokasi perhatian seseorang dalam proses mendapatkan informasi. Dalam sudut pandang orang lain Jim Loehr Tony berpendapat bahwa emosi negatif merupakan pemborosan dan tidak efisien seperti halnya sebuah mobil yang boros bahan bakar sehingga dengan cepat dapat menghabiskan isi tangki bahan bakar. Dalam hal ini ada dua cara untuk mengontrol dan mengelola kondisi emosi negatif yang muncul, pada saat emosi negative timbul, seperti marah, takut, kecewa, malas, sedih, atau perasaan negative lainnya. Maka anda harus mencari penyebab hadirnya emosi negative tersebut. Ingatlah bahwa emosi dan tubuh anda merupakan satu kesatuan yang tidak dapat dipisahkan. Anda akan mengelola emosi negative menjadi emosi positif dengan mengubah cara pisiologis seperti cara bernafas, berdiri dan espresi wajah.

Pengertian kontrol diri merupakan suatu kecakapaan individu dalam kepekaan membaca situasi kemampuan diri dan lingkungan serta kemampuan untuk mengontrol dan mengelola faktor-faktor perilaku siswa dengan situasi dan kondisi untuk menampilkan diri dalam melakukan sosialisasi kemampuan untuk mengendalikan perilaku kecendrungan untuk menarik perhatian keinginan untuk mengubah perilaku agar sesuai untuk orang lain, selalu nyaman dengan orang lain menutup perasaannya. Menurut Goleman Kontrol Diri adalah keterampilan untuk mengendalikan diri 
dari api-api emosi yang terlihat mencolok. Tanda-tandanya meliputi ketegangan saat menghadapi stress atau menghadapi seseorang yang bersikap bermusuhan tanpa membalas dengan sikap atau perilaku serupa. Skiner menyatakan bahwa kontrol diri merupakan tindakan dari dalam mengontrol variabel-variabel luar yang menentukan tingkah laku Dan tingkah laku dapat dikontrol melalui berbagai cara yaitu menghindar, penjenuhan, stimuli yang tidak disukai, dan memperkuat diri.

Berdasarkan konsep Averill, terdapat 3 jenis kemampuan dengan sebutan kontrol personal, yaitu kontrol perilaku (behavioral control), kontrol kognitif (cognitive control), dan mengontrol kepuasan (decisional control) (Nur Gufron \& Rini Risnawati, 2011). Behavioral control Merupakan kesiapan atau tersedianya suatu respon yang dapat secara langsung mempengaruhi atau memodifikasi suatu keadaan yang tidak menyenangkan. Cognitive control Kemampuan individu dalam mengelola informasi yang tidak diinginkan dengan cara menginterpretasi, menilai atau menggabungkan suatu kejadian dalam suatu kerangka kognitif sebagai adaptasi psikologis atau untuk mengurangi tekanan. Decisional control Merupakan kemampuan seseorang untuk memilih suatu tindakan berdasarkan pada sesuatu yang diyakini atau disetujuinya.

Nur Gufron \& Rini Risnawati (2011) menjelaskan Jenis-jenis Kontrol Diri dibagi menjadi tiga yaitu: Over control merupakan kontrol diri yang dilakukan oleh individusecara berlebihan yang menyebabkan individu banyak menahan diri beraksi terhadapstimulus. Under control merupakan suatu kecenderungan individu untuk melepaskan implus dengan bebas tanpa perhitungan yang masak. Appropriate control merupakan kontrol individu dalam upaya mengendalikan implus secara tepat. Informational control merupakan kesempatan untuk mendapat informasi mengenai kejadian yang menekan, kapan terjadi, mengapa dan apa konsekuensinya. Retrospective control merupakan kemampuan untuk menyinggung tentang kepercayaan mengenai apa atau siapa yang menyebabkan sebuah peristiwa yang menekan setelah hal tersebut terjadi.

\section{METODE PENELITIAN}

Metode penelitian pada dasarnya merupakan cara ilmiah untuk mendapatkan data dengan tujuan dan kegunaan tertentu (Sugiyono, 2011). Dalam metode ini, salah satu cara yang dilakukankan untuk mendapatkan data secara ilmiah ialah dengan metode empiris. "Metode empiris merupakan cara-cara yang dilakukan itu dapat diamati oleh indra manusia, sehingga orang lain dapat mengamati dan mengetahui cara-cara yang digunakan". Sedangkan yang dimaksud dengan "Metode eksperimen merupakan satu bentuk kegitan penelitian yang dilakukan oleh peneliti untuk menimbulkan dengan gejala variabel yang diteliti" (Suharsimi, 2014). Sesuai dengan penelitian ini maka metode atau pendekatan yang digunakan adalah metode atau pendekatan empiris sesuai dengan penjelasan diatas, karena yang akan diteliti baik variabel bebas (Independent) tentang hubungan Kestabilan emosi maupun variabel terikat (dependent) tentang Kontrol diri sudah ada secara wajar dan tidak perlu diadakan percobaan atau eksperimen.

Dalam sebuah sumber menjelaskan bahwa "rancangan dalam suatu penelitian akan sangat ditentukan oleh jenis kegiatan penelitian yang akan dilakukan oleh peneliti" Ahli lain mengatakan bahwa "rancangan pada dasarnya merupakan "keseluruhan proses pemikiran dan penentuan matang tentang 
hal-hal yang akan dilakukan serta dapat dijadikan dasar penilaian baik dari peneliti itu sendiri maupun orang lain terhadap kegiatan penelitian dengan tujuan untuk memberi pertanggungjawaban terhadap semua langkah yang akan diambil" (Margono, 2010). Berdasarkan beberapa pendapat di atas, maka peneliti dapat menyimpulkan bahwa yang dimaksud rancangan penelitian adalah penggambaran mengenai keseluruhan proses aktivitas peneliti selama kerja penelitian mulai dari persiapan sampai dengan pelaksanaan penelitian, serta mempertanggung jawabkan terhadap semua langkah-langkah yang diambil. Rancangan penelitian ini memiliki dua variabel, yaitu variabel bebas (Kesetabilan emosi) dan variabel terikat sebagai variable Y (Kontrol diri).Berdasarkan kedua variabel tersebut, peneliti dapat melakukan pengumpulan data dengan metode angket untuk masing-masing variabel dan metode dokumentasi sebagai metode pelengkap.Setelah mendapatkan data melalui angketuntuk mengetahui tingkat kestabilan emosi dengan kontrol diri siswa peneliti menganalisis data dengan rumus korelasi product moment dan menarik kesimpulan dari data yang diperoleh.

Populasi adalah wilayah generalisasi yang terdiri atas: obyek/subyek yang mempunyai kualitas dan dan karakteristik tertentu yang ditetapkan oleh peneliti untuk dipelajari dan kemudian ditarik kesimpulan" (Sugiyono, 2011). Sedangkan ahli lain menyatakan bahwa "populasi adalah keseluruhan subyek penelitian" (Suharsimi, 2014). Berdasarkan kedua pendapat diatas, maka yang dimaksud dengan populasi adalah keseluruhan subyek dan obyek penelitian yang mempunyai kualitas dan karakteristik yang ditetapkan oleh peneliti untuk dipelajari dan kemudian ditarik kesimpulannya. Dalam penelitian ini yang menjadi subyek penelitian ini adalah sebanyak 323 siswa SMP.

Sampel adalah bagian dari jumlah dan karakteristik yang dimiliki oleh populasi tersebut" (Sugiyono, 2011).Sementara ahli lain menyatakan bahwa "Sampel adalah sebagian atau wakil populasi yang diteliti" (Suharsimi, 2014). Berdasarkan pendapat tersebut, maka sampel yang dimaksud dalam penelitian ini adalah sebagian dari populasi yang akan diteliti. Dalam penelitian ini yang menjadi subyek berjumlah 119 Siswa. Melihat jumlah subyek siswa SMP yang terlalu banyak, maka untuk menentukan sampelnya disesuaikan dengan proporsi yang sesuai, yaitu untuk penentuan subyek kestabilan emosi dan kontrol diri diambil masingmasing 25\%. Hal ini sejalan dengan pendapat yang menyatakan bahwa "Jika populasi kurang dari 100, dianjurkan agar semuanya dijadikan sampel, tapi jika populasi lebih dari 100, dapat diambil $10-15 \%$, 20-25\% atau lebih tergantung kemampuan peneliti" (Suharsimi, 2014). Setelah ditetapkan jumlah sampel siswa yang akan dikenakan dalam penelitian ini yaitu sebesar $25 \%$ maka pengambilan sampel siswa pada masing-masing kelas tersebut akan dilakukan dengan menggunakan teknik random sampling. "Instrumen penelitian adalah suatu alat yang digunakan mengukur fenomena alam maupun sosial yang diamati" (Sugiyono, 2011). Sedangkan ahli lain menjelaskan bahwa "Instrumen penelitian adalah alat bantu bagi peneliti dalam mengumpulkan data" (Suharsimi, 2014). Berdasarkan kedua pendapat di atas, maka yang dimaksud dengan instrumen adalah suatu alat bantu yang digunakan untuk memperoleh data tentang objek yang diteliti. Mengingat penelitian ini menggunakan pendekatan empiris dimana data-data yang diperoleh 
sudah ada secara wajar tanpa adanya eksperimen maka instrumen yang digunakan untuk pengumpulan data adalah dengan menggunakan instrumen angket dalam bentuk skala Likert, untuk mendapatkan data tentang hubungan kestabilani emosi dengan kontrol diri.

Teknik pengumpulan data merupakan langkah yang digunakan untuk mengumpulkan data-data (Sugiyono. 2014). Dalam penelitian ini metode pengumpulan data yang dipakai adalah metode angket sebagai metode pokok dan metode dokumentasi, observasi serta metode wawancara/interview sebagai metode pelengkap. Setelah data terkumpul maka langkah selanjutnya adalah mengolah data/menganalisis data tersebut secara statistik. Dalam buku Metode Penelitian Kuantitatif Kualitatif dan $R \& D$ menyatakan "Analisis data merupakan proses mencari dan menyusun bahan secara sistematis data yang diperoleh dari hasil wawancara, catatan lapangan, dan bahan-bahan lain, sehingga dapat mudah dipahami, dan temuannya dapat diinformasikan kepada orang lain" (Sugiyono, 2011). Metode analisis data merupakan tata cara yang harus diikuti atau digunakan oleh peneliti dalam rangka menganalisis data yang sudah dikumpulkan untuk memperoleh kesimpulan. Dalam penelitian ini data yang akan diperolah adalah data tentang hubungan Kestabilan emosi dengan Kontrol diri, maka data yang diproleh adalah data yang didapat dengan menyelidiki kategori, sifat atau ciri seseorang yang bersifat data kuantitatif dalam bentuk angka. Kemudian langkahlangkah pelaksanaan analisis statistik sebagai cara untuk mengolah data/untuk memperoleh hasil yang sesuai dengan yang diharapkan (data processing, pengorganisasian data dan penemuan hasil penelitian). Dalam penelitian ini menggunakan teknik kerja korelasi product moment.

\section{HASIL PENELITIAN DAN PEMBAHASAN}

Sehubungan dengan analisis data yang menggunakan analisis statistik, maka hipotesis alternatif (Ha) yang diajukan berbunyi: Adanya Hubungan Antara kestabilan emosi Dengan Kontrol Diri Siswa SMP, perlu dirumuskan terlebih dahulu menjadi hipotesis nihil (Ho) yang berbunyi " Tidak ada Hubungan antara Kestabilan emosi dengan kontrol diri siswa SMP" Dari hasil perhitungan nilai rxy yang diperoleh dalam penelitian ini adalah 0,384 sedangkan nilai rxy dalam tabel dengan taraf signifikan 5\% dan $\mathrm{N}=$ 30 adalah 0,361, kenyataan ini menunjukkan bahwa nilai rxy yang diperoleh dalam penelitian ini adalah lebih besar dari pada nilai rxy tabel. Maka dapat dikemukakan bahwa hipotesis nol (Ho) ditolak dan hipotesis alternatif (Ha) diterima. Jadi kesimpulan analisis dalam penelitian ini adalah sebagai berikut: "Ada hubungan Antara kestabilan emosi dengan kontrol diri siswa di SMP".

Pada uraian berikut ini peneliti memberikan pembahasan secara menyeluruh. Karena penelitian ini merupakan penelitian Hubunngan yang menggunakan metode angket, maka dalam uraian pembahasan ini akan digambarkan hasil-hasil dari pengumpulan data dan analisis data yang diperoleh dari angket kestabilan emosi dan angket kontrol diri, kemudian akan diungkap satu demi satu data dari angket yang bertujuan ingin mengetahui ada hubungan antara kestabilan emosi dengan kontrol diri Siswa. Maka hasil penelitian ini menunjukan bahwa hubungan antara kestabilan emosi dengan kontrol diri siswa SMP menunjukan taraf "Signifikan" karena yang sangat berhubungan. Seperti yang dikeahui 
siswa yang memiliki kestabilan emosi yang baik akan mudah menyesuaikan diri dengan lingkungannya.

Kestabilan eosi adalah keaadaan individu yang memiliki emosi yang matang Ketika mendapatkan rangsangan dari luar tidak menimbulkan gangguan emosional, memiliki keseimbangan yang baik dan mampu menghadapi segala sesuatu dengan kondisi emosi yang tetap. Goleman menyatakan bahwa emosi berperan besar dalam suatu tindakan, bahkan dalam pengambilan keputusan yan paling rasional, perasaan sangat dibutuhkan dalam pengambilan keputusan yang rasional, selain itu keadaan emosional individu dapat membantu mengatasi konflik secara tepat. Kestabilan emosi merupakan suatu kemampuan yang dimiliki oleh seorang individu dalam mengontrol emosinya dengan cara menampilkan reaksi yang tepat atas rangsang yang diterima, sehingga individu mampu menyesuaikan diri dengan kondisi yang sedang dialami maupun berhubungan dengan orang lain (Santrock, 2003).

Stabilitas yang di maksud adalah reaksi individu baik secara emosi maupun fisik, individu yang memilki stabilitas emosi yang baik adalah individu yang mampu memahami apa yang sedang dirasakan dan mengekspresikannya secara tepat. Sebaliknya, individu yang memiliki stabilitas yang rendah emosinya digambarkan sebagai individu yang sulit mengenali apa yang dirasakan sebenarnya, dan melampiaskan perasaannya dengan cara yang destruktif. Karakteristik stabilitas emosi antara lain mampu merespon perubahan situasi dengan baik, mampu menunda respon terutama respon negatif, bebas dari rasa takut yang tidak beralasan, dan mau mengakui kesalahan tanpa malu.

Pada keadaan emosi yang stabil individu berfikir dan bertindak secara realitas. Emosi yang stabil individu seperti inilah yang dapat menyelesaikan segala permasalahan yang dihadapi dengan emosi stabil atau tenang, dari memiliki emosi yang stabil seperti itu individu dapat mengambil keputusan dengan cepat dan tepat serta kepala dingin. Jika sebaliknya, individu yang kurang mampu mengelolah emosi dan tidak memiliki emosi yang stabil seperti gugup, cemas, individu seperti inilah yang akan sulit mengambil keputusan, dan lamban, dan terkadang tidak sesuai dengan harapan.

Dalam penelitian ini aspek-aspek kestabilan emosi terdiri dari respon emosi, kematangan emosi, dan kontrol emosi. Aspek-aspek dari kestabilan emosi yaitu: kontrol emosi yang meliputi pengaturan emosi dan perasaan sesuai dengan tuntutan lingkungan atau situasi dan standar dalam diri individu yang berhubungan dengan nilai-nilai, cita-cita, prinsip, bentui respon emosi yang dipilih dan ditampilkan individu saat menghadapi situasi tertentu, dan kematangan emosi yaitu kemampuan individu untuk melakukan respon emosi yang sesuai dengan tingkat perkembangannya yang diindikasikan dengan adanya kemampuan untuk menyesuaikan diri terhadap stress, tidak mudah khawatir, tidak mudah cemas, dan tidak mudah marah.

Calhoun dan Acocella (Ghufron \& Rini 2016) menyatakan bahwa kontrol diri sebagai pengaturan Proses-proses fisik, psikologis, dan perilaku seseorang, dengan kata lain serangkaian proses yang membentuk dirinya sendiri. Dalam rangka membantu dalam meningkatkan kontrol diri dalam belajar pada siswa dan tidak kalah penting juga adalah orang tua/wali murid, hendaknya terus mendorong dan mengarahkan anakanaknya dengan sebaik-baiknya dalam peroses pembelajaran yang berlangsung di sekolah, sehingga mereka akan dapat 
diterima oleh lingkungannya, baik lingkungan keluarga, sekolah maupun lingkungan masyarakat sekitarnya yang pada akhirnya akan mendatangkan perubahan sikap, sehingga ia akan mendapatkan prestasi yang baik atau memuaskan di dalam bidang pendidikan.

Pada dasarnya kestabilan emosi siswa dilibatkan dengan lingkungan sekolah dan lingkungan luar, dalam penelitian ini kontrol diri siswa sangat berhubungan baik secara langsung maupun tidak langsung. Berdasarkan pembahasan diatas mengenai ada tidaknya hubungan antara kestabilan emosi dengan kontrol diri siswa, sehingga peneliti dapat menyimpulkan bahwa hasil penelitian yang diperoleh serta hasil analisis data dimana nilai rxy hitung sebesar 0,384 dan nilai rxy tabel pada taraf signifikan 5\% dengan $\mathrm{N}=30$ sebesar 0,361 lebih besar dari pada nilai rxy hitung $(0,384>0,361)$. Sehingga ada hubungan yang "Signifikan" antara kestabilan emosi dengan kontrol diri siswa di SMP.

\section{KESIMPULAN DAN SARAN}

Dari hasil penelitian dan analisis data diperoleh nilai $r x y$ hitung adalah 0.384 sedangkan nilai $r x y$ dalam tabel dengan taraf signifikan 5\% dan $\mathrm{N}=30$ adalah 0,361 lebih besar dari pada rxy hitung $(0,384>0,361)$, Sehingga dapat disimpulkan bahwa ada Hubungan yang "Signifikan" antara kestabilan emosi dengan kontrol diri Siswa SMP.

Bagi Kepala Sekolah agar memberikan dukungan/motivasi serta informasi kepada rekan-rekan guru, bahwa pelaksanaan Bimbingan dan Konseling sangat bermanfaat bagi siswa, terutama dalam membantu siswa dalam perkembangan sosialnya. Kepada guru bidang studi, khususnya guru BK supaya lebih meningkatkan dalam memberikan layanan bimbingan dan konseling tentang pentingnya menjaga kestabilan emosi dengan kontrol diri dan lingkungan sekitar kepada para siswa. Kepada para wali siswa kelas VIII di rumah diharapkan untuk menanamkan kestabilan emosi sejak dini terhadap anak-anaknya, agar anak dapat mengembangkan kemampuannya bersosialisasi baik dalam lingkungan keluarga, sekolah maupun masyarakat. Kepada peneliti selanjutnya agar meneliti aspek-aspek lain yang lebih luas. Kemungkinan dalam penelitian ini belum ada yang terungkap.

\section{DAFTAR PUSTAKA}

Aluh Hartati, Hariadi Ahmad dan Andika Rifzar Mandasingi. 2020. Hubungan antara Pengendalian Diri dengan Prestasi Siswa SMKN 1 Sumbawa Besar. Realita Jurnal Bimbingan dan Konseling Vol. 5 No 2 Edisi Oktober 2020. Hal 1051 - 1066. Prodi Bimbingan dan Konseling Fakultas Ilmu Pendidikan dan Psikologi Universitas Pendidikan Mandalika.

Coky Aditya Z, 2013, Terapi Beragam masalah Emosi Harian, Banguntapan Jogjakarta, PT Sabil.

Gerungan, WA.

2009. Psikologi Sosial. Bandung :

PT. Refika Aditama

Goleman Daniel, 2005, Pisikologi Remaja, PT Bumi Aksa, Jakarta.

Goleman Daniel. 1999. Working with Emotional Intelligence:

Kecerdasan Emosi untuk

Mencapai Puncak Prestasi (penerjemah Alex Tri Kantjo Widodo). Jakarta: Gramedia Pustaka Utama.

Goleman, D. 1997. The groundbreaking book that redefines what it means to be smart, Emotional 
Intelligence Why it can matter more than IQ. The 10th anniversary edition. New York. Bantam Books.

Goleman, D. 2001. Working Whit Emotional Intelligence:

Kecerdasan Emosi untuk Mencapai Puncak Prestasi. Jakarta. PT Garamedia.

Hariadi Ahmad dan Aluh Hartati. 2016.

Panduan Pelatihan Self Advocacy

Siswa SMP untuk Konselor

Sekolah. LPP Mandala. Mataram

Hariadi Ahmad dan Aluh Hartati. 2016.

Penerapan Teknik Structure

Learning Approach dalam

Meningkatkan Self Advocacy

Mahasiswa Prodi BK IKIP

Mataram. Realita Jurnal

Bimbingan dan Konseling Vol. 1

No 2 Edisi Oktober 2016. Hal 117

- 127. Prodi Bimbingan dan

Konseling Fakultas Ilmu

Pendidikan IKIP Mataram

Hariadi Ahmad dan Dini Kurnia. 2017.

Pengaruh Teknik Biblio Edukasi

Terhadap Rasa Rendah Diri Pada

Siswa Kelas XI di SMA Negeri 8

Mataram. Realita Jurnal

Bimbingan dan Konseling Vol. 2

No 1 Edisi April 2017. Hal $194-$

202. Prodi Bimbingan dan

Konseling Fakultas Ilmu

Pendidikan IKIP Mataram

Hariadi Ahmad, Ahmad Zainul Irfan dan

Dedi Ahlufahmi. 2020. Hubungan

antara Pola Asuh Orang Tua dengan Penyesuaian Diri Siswa.

Realita Jurnal Bimbingan dan Konseling Vol. 5 No 1 Edisi April 2020. Hal 950 - 966. Prodi Bimbingan dan Konseling Fakultas Ilmu Pendidikan dan Psikologi Universitas Pendidikan Mandalika.

Hariadi Ahmad, Aluh Hartati dan Jessica Festy Maharani. 2020. Pengaruh
Dukungan Psikologis Awal pada Remaja dalam Pencegahan Covid 19. Realita Jurnal Bimbingan dan Konseling Vol. 5 No 2 Edisi Oktober 2020. Hal 1091 - 1106. Prodi Bimbingan dan Konseling Fakultas Ilmu Pendidikan dan Psikologi Universitas Pendidikan Mandalika.

Hariadi Ahmad, Aluh Hartati, dan Nuraeni. 2018. Penerapan Teknik Structure Learning Approach (SLA) dalam Meningkatkan Kesadaran Empati Diri Siswa Madrasah Aliyah Al Badriyah. Realita Jurnal Bimbingan dan Konseling Vol. 3 No 2 Edisi Oktober 2018. Hal 600 - 605 Prodi Bimbingan dan Konseling Fakultas Ilmu Pendidikan IKIP Mataram.

Hariadi Ahmad, dan Lalu Andry Adifa Maulana. 2019. Pengaruh Teknik Video Edukasi Terhadap Berfikir Positif Siswa SMPN 16 Mataram. Realita Jurnal Bimbingan dan Konseling Vol. 4 No 1 Edisi April 2019. Hal 727 - 741. Prodi Bimbingan dan Konseling Fakultas Ilmu Pendidikan IKIP Mataram.

Hariadi Ahmad, dan Yolana Oktaviani. 2019. Pengaruh Teknik Self Instruction Terhadap Harga Diri Siswa Kelas Kelas XI di SMK Negeri 1 Lingsar Kabupaten Lombok Barat. Realita Jurnal Bimbingan dan Konseling Vol. 4 No 2 Edisi Oktober 2019. Hal 806 - 815. Prodi Bimbingan dan Konseling Fakultas Ilmu Pendidikan IKIP Mataram.

Hariadi Ahmad, Lidya Wurru dan Jessica Festy Maharani. 2021. Hubungan antara Keharmonisan Keluarga dengan Perilaku Agresif pada Siswa Madrasah Aliyah Raudlatusshibyan NW 
Belencong. Realita Jurnal Suharsimi Arikunto. 2014. Prosedur Bimbingan dan Konseling Vol. 6 No 1 Edisi April 2021. Hal 1205 - 1212. Prodi Bimbingan dan Konseling Fakultas Ilmu Pendidikan dan Psikologi Universitas Pendidikan Mandalika.

Hariadi Ahmad, Mustakim dan Syafaruddin. 2018. Hubungan antara Penyesuaian Diri dengan Berfikir Positif Siswa Kelas VIII SMP Negeri Seteluk Kabupaten Sumbawa Barat. Realita Jurnal Bimbingan dan Konseling Vol. 3 No 1 Edisi April 2018. Hal 482 494. Prodi Bimbingan dan Konseling Fakultas Ilmu Pendidikan IKIP Mataram

Hasrul dan Hariadi Ahmad. 2021. Mereduksi Prasangka Etnik Siswa dengan Teknik Restructuing Cognitive Suatu Krangka Konseptual. Realita Jurnal Bimbingan dan Konseling Vol. 6 No 1 Edisi April 2021. Hal 1213 - 1222. Prodi Bimbingan dan Konseling Fakultas Ilmu Pendidikan dan Psikologi Universitas Pendidikan Mandalika.

M. Nur Ghufron, Rini Risnawati. 2011. Teori Teori Psikologi, Jogjakarta, Ar-Ruzz Media.

Margono. 2010. Metodologi Penelitian Pendidikan. Jakarta: PT. Rineka Cipta.

Santrock, J. W. 2003. Perkembangan Masa Remaja. Jakarta: Erlangga.

Stephen P. Robbins \& Timothy A. Judge. 2008. Perilaku Organisasi Edisi 2. Jakarta: Salemba Empat.

Sugiyono. 2014. Metode Penelitian Pendidikan, Pendekatan Kuantitatif, Kualitatif, dan R\&D. Bandung: Alfabeta.

Penelitian Suatu Pendekatan Praktik. Jakarta: Rineka Cipta. 


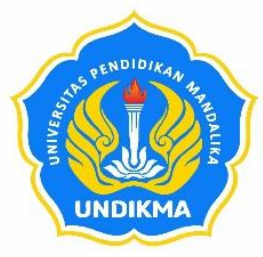

\section{UNIVERSITAS PENDIDIKAN MANDALIKA FAKULTAS ILMU PENDIDIKAN DAN PSIKOLOGI PROGRAM STUDI BIMBINGAN DAN KONSELING Jurnal Realita}

Gedung Dwitiya Lt.3. Jln Pemuda 59A Mataram-NTB 83125 Tlp (0370) 638991 e-mail: realita@undikma.ac.id; web: e-journal.undikma.ac.id

\section{PEDOMAN PENULISAN}

1. Naskah merupakan hasil penelitian, pengembangan atau kajian kepustakaan di bidang pendidikan, pengajaran, pembelajaran, bimbingan dan konseling, dan Psikologi

2. Naskah merupakan tulisan asli penulis dan belum pernah dipublikasikan sebelumnya dalam jurnal ilmiah lain,

3. Naskah dapat ditulis dalam Bahasa Indonesia atau Bahasa Inggris.

4. Penulisan naskah mengikuti ketentuan sebagai berikut:

$\begin{array}{llll}\text { Program } & \text { MS Word } & \text { Margin kiri } & 3.17 \mathrm{~cm} \\ \text { Font } & \text { Times New Roman } & \text { Margin kanan } & 3.17 \mathrm{~cm} \\ \text { Size } & 12 & \text { Margin atas } & 2.54 \mathrm{~cm} \\ \text { Spasi } & 1.0 & \text { Margin bawah } & 2.54 \mathrm{~cm} \\ \text { Ukuran kertas } & \text { A4 } & \text { Maksimum 20 halaman }\end{array}$

5. Naskah ditulis dengan sistematika sebagai berikut: Judul (huruf biasa dan dicetak tebal), nama-nama penulis (tanpa gelar akademis), instansi penulis (program studi, jurusan, universitas), email dan nomor telpon penulis, abstrak, kata kunci, pendahuluan (tanpa sub-judul), metode penelitian (tanpa sub-judul), hasil dan pembahasan, simpulan dan saran (tanpa sub-judul), dan daftar pustaka.

Judul secara ringkas dan jelas menggambarkan isi tulisan dan ditulis dalam huruf kapital. Keterangan tulisan berupa hasil penelitian dari sumber dana tertentu dapat dibuat dalam bentuk catatan kaki. Fotocopy halaman pengesahan laporan penelitian tersebut harus dilampirkan pada draf artikel.

Nama-nama penulis ditulis lengkap tanpa gelar akademis.

Alamat instansi penulis ditulis lengkap berupa nama sekolah atau program studi, nama jurusan dan nama perguruan tinggi. Penulis yang tidak berafiliasi pada sekolah atau perguruan tinggi dapat menyertakan alamat surat elektronik dan nomor telpon.

Abstrak ditulis dalam 2 (dua) bahasa: Bahasa Inggris dan Bahasa Indonesia. Naskah berbahasa Inggris didahului abstrak berbahasa Indonesia. Naskah berbahasa Indonesia didahului abstrak berbahasa Inggris. Panjang abstrak tidak lebih dari 200 kata. Jika diperlukan, tim redaksi dapat menyediakan bantuan penerjemahan abstrak kedalam bahasa Inggris.

Kata kunci (key words) dalam bahasa yang sesuai dengan bahasa yang dipergunakan dalam naskah tulisan dan berisi 3-5 kata yang benar-benar dipergunakan dalam naskah tulisan.

Daftar Pustaka ditulis dengan berpedoman pada Pedoman Penulisan Karya Ilmiah Universitas Pendidikan Mandalika. 


\begin{tabular}{|c|c|c|c|c|c|}
\hline & & & & \\
JURNAL & VOLUME & NOMOR & EDISI & HALAMAN & P ISSN : 2503 - 1708 \\
REALITA & 6 & 2 & Oktober 2021 & $1326-1430$ & E ISSN : 2722 - 7340 \\
& & & & \\
\hline
\end{tabular}

Alamat Qedaksi:

Program Studi Bimbingan dan Konseling Fakultas Ilmu Pendidikan dan Psikologi

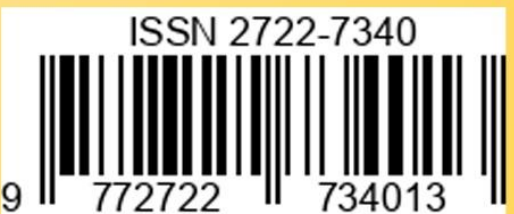

Universitas Pendidikan Mandalika

Gedung Dwitiya, Lt. 3 Jalan Pemuda No. 59A Mataram Telp. (0370) 638991

Email : realita@undikma.ac.id

Web : e-journal.undikma.ac.id

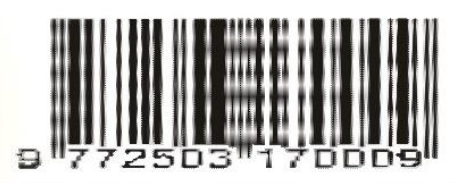

